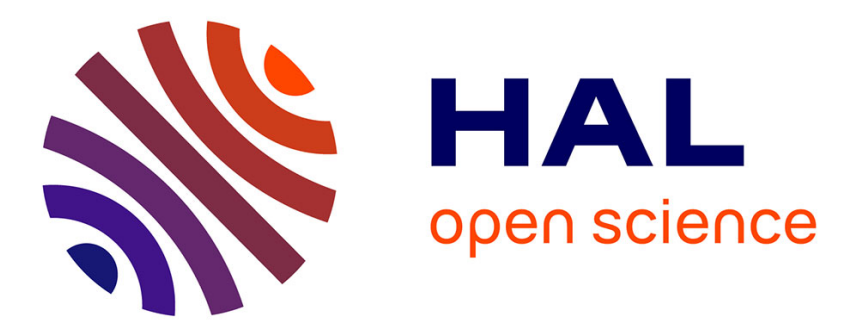

\title{
Multi-level governance, regions and science in France: between competition and equality
}

\author{
Cécile Crespy, Jean-Alain Héraud, Beth Perry
}

\section{To cite this version:}

Cécile Crespy, Jean-Alain Héraud, Beth Perry. Multi-level governance, regions and science in France: between competition and equality. Regional Studies, 2007, 41 (08), pp.1069-1084. 10.1080/00343400701530840 . hal-00514676

\section{HAL Id: hal-00514676 \\ https://hal.science/hal-00514676}

Submitted on 3 Sep 2010

HAL is a multi-disciplinary open access archive for the deposit and dissemination of scientific research documents, whether they are published or not. The documents may come from teaching and research institutions in France or abroad, or from public or private research centers.
L'archive ouverte pluridisciplinaire HAL, est destinée au dépôt et à la diffusion de documents scientifiques de niveau recherche, publiés ou non, émanant des établissements d'enseignement et de recherche français ou étrangers, des laboratoires publics ou privés. 


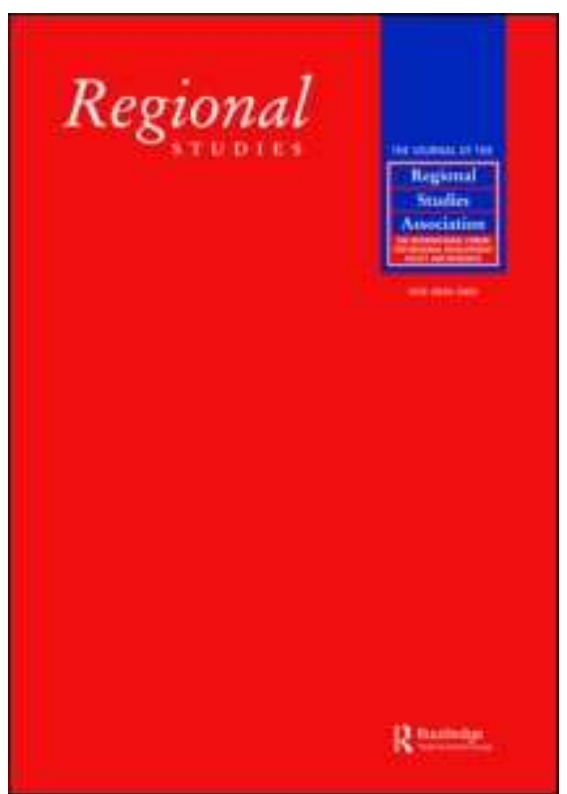

\section{Multi-level governance, regions and science in France: between competition and equality}

\begin{tabular}{|c|c|}
\hline Journal: & Regional Studies \\
\hline Manuscript ID: & CRES-2006-0098.R1 \\
\hline Manuscript Type: & Main Section \\
\hline JEL codes: & $\begin{array}{l}\text { H1 - Structure and Scope of Government < H - Public Economics, } \\
\text { O3 - Technological Change|Research and Development < O - } \\
\text { Economic Development, Technological Change, and Growth, R11 - } \\
\text { Regional Economic Activity: Growth, Development, and Changes < } \\
\text { R1 - General Regional Economics < R - Urban, Rural, and Regional } \\
\text { Economics, R58 - Regional Development Policy < R5 - Regional } \\
\text { Government Analysis < R - Urban, Rural, and Regional Economics }\end{array}$ \\
\hline Keywords: & $\begin{array}{l}\text { structure and scope of government, regional government analysis, } \\
\text { technological change }\end{array}$ \\
\hline
\end{tabular}

\section{SCHOLARONE \\ Manuscripts}


Multi-level governance, regions and science in France: between competition and equality

\author{
Cecile Crespy \\ Post-doctoral Researcher \\ Laboratoire d'Economie et de Sociologie du Travail \\ 35 Avenue Jules Ferry \\ 13626 AIX-EN-PROVENCE Cedex 01 \\ cecile.crespy@univmed.fr \\ Jean-Alain Heraud \\ Professor of Economics \\ BETA Université Louis Pasteur et CNRS \\ Faculté des Sciences Economiques et de Gestion \\ 61, avenue de la Forêt Noire \\ 67085 STRASBOURG CEDEX \\ heraud@cournot.u-strasbg.fr \\ Beth Perry \\ Research Fellow \\ Centre for Sustainable Urban and Regional Futures \\ University of Salford \\ 113-115 Portland Street \\ Manchester \\ M1 6DW \\ b.perry@salford.ac.uk
}

\begin{abstract}
This article examines the relevance of the concept of multi-level governance for understanding changes in science policy in France. It explores the emergence of a pattern of multi-level governance, particularly in relation to arenas for negotiation between national and regional levels. Compromises are made between the principles of competition and equality and there is great diversity across regions in terms of the capacities for developing bottom-up strategies for science-based development. The article highlights the prerequisites for the development of a multi-level polity and emphasises the continued role that central government retains in the global design of science policy.
\end{abstract}

KEY WORDS: multi-level governance, science, regions, France, competition, equality

JEL CODES: H1, O3, R11, R58 


\section{INTRODUCTION}

It is widely acknowledged that the sovereignty of the nation-state has been eroded. Commentators have focussed on globalisation and internationalisation as indicative of shifts in supra-national governance, while others have emphasised the importance of sub-national actors and the rise of the 'region state' (OHMAE 1993). Attention has been drawn to changing notions of governance in terms of the involvement of non-state actors, as much as the reallocation of decisional responsibilities between tiers of government. Multi-level governance rejects an either/or approach and focuses on the subtle processes through which supra-national and sub-national governmental and non-governmental agencies are encroaching on traditionally centralised policy areas (MARKS 1993. BACHE AND FLINDERS 2004).

The case of science policy offers a fertile arena for examination of multi-level governance dynamics. Within Europe, for instance, the European Research Area (ERA) initiative or the development of a European Research Council (ERC) indicate a strengthening supra-national tier of governance. This has been accompanied by the emergence of regional science policies as elected regional governments, development agencies and city partners attach increasing importance to science as a tool in economic growth. The distinction between science policy and innovation policy is important here. Whilst regional authorities have long engaged in innovation activities, particularly those aimed at SMEs (CHABBAL 1995), regional policy makers have shown reluctance to fund scientific activities or institutions. Throughout the 2000s, however, the frontiers between science and innovation policies have become blurred, due to the increasing relationship between science and wealth creation, the changing nature of relevant science and technology (S\&T) fields and the new constraints of public finance that have led to increased co-funding schemes. Such changes have brought new actors into the science and innovation policy field, among them regional governments and agencies, 
but also non-state actors, reflecting both vertical and horizontal shifts in science policy governance.

This article assesses the relevance of the concept of multi-level governance in science policy in France. The French case provides unique insights to the challenges of multi-level governance in a country with a long-standing tradition of centralist administration and a strong attachment to the principles of equality and balanced growth. The French regions have traditionally had no official competence in the management and organisation of the research system and have generally been considered as a weak level of government in relation to their international comparators (LE GALES and LEQUESNE, 1998). In the last years, however, regions have emerged as intermediate actors in complex governance structures and spaces for the negotiation of science policy between national and regional actors have been created. Yet the pattern of regional involvement in science policy is not even; considerable diversity and variability can be seen, reflecting new compromises between the principles of competition and equality.

This article reflects recent research activities (2004-2006) on regional and local science-based growth in Europe, funded by the European Commission and the UK's Economic and Social Research Council. ${ }^{1}$ The research has included interviews at national and regional levels, extensive documentary analysis and the collation of data on French regions through national ministry sources and national evaluations. The paper is organised in three sections. First, we begin by reviewing the literature on multi-level governance and the challenges that a multi-level, multi-actor science policy system poses to the French State. The second section considers the empirical material in terms of an enlarged regional dimension to national science and innovation policy; arenas for negotiation and the capacities of regions to

\footnotetext{
${ }^{1}$ The ERA-Spaces project within the EU PRIME Network of Excellence and the 'Building Science Regions' project funded by the UK Economic and Social Research Council's Science in Society programme (RES-15125-0037). The support of both funders is gratefully acknowledged.
} 
develop bottom-up strategies for science-based growth. A final section reviews the lessons of the French case for the wider debate on multi-level governance, regions and science.

\section{MULTI-LEVEL, MULTI-ACTOR SCIENCE GOVERNANCE IN FRANCE \\ Identifying multi-level governance}

The increasing complexity of governance structures can be seen as both a response to the crisis of legitimacy of the State and to greater demands for democracy (KoOIMAN, 1990). Authors have emphasised the weakness of the state due to fiscal crisis, decentralisation and administrative reforms and the introduction of new forms of public management as bringing about a wider shift from government to governance (PETERS and PIERRE, 2001). Problemsolving is no longer seen as necessarily corresponding to one authority or to a specific institutional territory. Instead, governance can refer to institutions and actors drawn from and beyond government; the blurring of boundaries and responsibilities for tackling social and economic issues; autonomous self-governing networks of actors; and the capacity for government to use new tools and techniques to steer and guide policy (STOKER 1998). Such propositions draw attention to the multiplicity of authorities and agencies involved in policy and employing a variety of techniques and forms of knowledge (DEAN, 1999).

Multi-level governance appears as a useful tool to capture these processes and describe evolving political systems, referring to the "the dispersion of central government authority both vertically to actors located at other territorial levels, and horizontally, to non state-actors" (BACHE AND FLINDERS 2004 : 4). It presupposes that authority is polycentric, shared between multiple actors, territorial levels and with each level disposing of specific resources (CONZELMANN 1998. BENZ AND EbeRLEIN 1999). Negotiation, non-hierarchical exchanges between levels of government and horizontal relationships at each scale of government are seen to be important features (PETERS AND PIERRE 2001). Yet criticisms have focused on its 
lack of robustness as an analytical term (JORDAN, 2001) and difficulties in its operationalisation.

In an attempt to address these concerns, HOOGHE and MARKS (2003) distinguish between two types of multi-level governance: type I and type II where the former is based on federalism and the latter a more variable geometry of organisation. Type I consists of power sharing between a few levels, non-intersecting governments in limited areas and stable authority. Type II is defined by many jurisdictions, which are task specific, intersecting and more flexible. Yet within this typology multi-level governance remains defined as a normative concept rather than an analytical tool. Acknowledging different types of multi-level governance does not necessarily enable the initial identification of a multi-level polity.

What then are the critical tests that indicate the extent and nature of the dispersion of state authority and the identification of multi-level governance? Decentralisation and processes of European integration have created a system of exchanges between different territorial levels such that relations are no longer state-centred. The emergence of relationships between institutions at different levels implies negotiation and dialogue, rather than hierarchical command and control relations. However, while actors, arenas and institutions are not ordered hierarchically, the questions of authority and the asymmetry of power have not totally disappeared. There is no necessary equality between institutions and some actors are more powerful than others. In multi-level governance theories, this is particularly the case in relation to national governments which can exploit new governance structures to increase their steering capacity. Similarly, it has been noted that the role of subnational authorities has been overemphasised in multi-level governance analyses (JORDAN 2001). What is at stake therefore is the nature of exchanges, distribution and management of resources and the relations between actors within each level of government. Arenas of negotiation and trade-offs, bargaining and potential conflicts between levels all illustrate the 
dynamics of multi-level governance in action. In addition, the capacity to take action becomes important as do mechanisms to coordinate public action (PETERS and PIERRE, 2001). On this basis, three criteria for operationalising multi-governance in any given policy area emerge: 1) the relative roles and responsibilities of territorial actors, with a diluted (albeit dominant) role for the central state 2) the existence and operation of arenas for negotiation and bargaining between national and regional actors in the definition of priorities and allocation of resources and 3) the capacities of different sub-national actors to exploit nationally-created opportunities and / or develop policy from the bottom-up. We shall return to these three tests later.

\section{National and Sectoral Diversity: Science Policy in France}

Multi-level governance has not been applied systematically across national settings or policy arenas. Country variables such as national politico-institutional settings, national policy styles and pre-existing institutionalised patterns of centre-periphery relations exert a strong influence on the extent of multi-level governance. (ConZELMANN, 1995. JoHN 1996). Some commentators have suggested that multi-level governance is a phenomenon which is structurally restricted to decentralised member states (JEFFREY, 1996, p.201). France has traditionally been seen as the archetype of a centralised country, yet processes of decentralisation over the last two decades have reshaped the pattern of centre-periphery relations (THOENIG, 2005). 'Co-administration' increasingly characterises relations between the state and local authorities (REIGNER 2001) yet the identification of actors is problematic in terms of the identification of appropriate levels of analysis (MCALEAVY AND DE RYNCK 1997. KeAting 1998). In France, as elsewhere, the notion of the 'region' can be disaggregated, composed of several sub-national levels: conseils régionaux, conseils généraux and communes. This only increases the potential actors and lines of authority that can gradually erode centralised control. 
Sectoral differences can also be observed (JoRDAn 2001. Peters AND PiERRE 2004). Whilst originally applied to regional policy in the EU, the environment (FAIRBRASS and JORDAN, 2004) or economic policy (PERRATON and WELLS, 2004) have also been subject to analysis through the lens of multi-level governance. However, there has been little systematic analysis of the shifting governance of science policy. Yet, recent developments around the construction of a European Research Area herald potentially significant changes in the territorial organisation of the European research infrastructure (for a wider discussion see EdLer, Kuhlmann AND Behrens 2003. BarRe et al, 1997). A corollary to supranational developments is an emphasis on the involvement of regional authorities as a prerequisite for achieving the Lisbon target of investing 3\% of GDP in R\&D by 2010 (EUROPEAN Commission, 2001). Some countries, of course, have a long history of regional involvement in science policy: Germany (KAISER, 2003), the US and Spain (SANZ-MENEDEZ and CRUZCASTRO, 2005) are key examples in light of their federal structures. The significant point is that regional involvement in science and higher education can be witnessed as a more general phenomenon, even in traditionally centralised countries such as the UK (see PERRY, THIS ISSUE), Japan (see KITAGAWA, THIS ISSUE) or France.

The debate over multi-level governance in science also takes place in the context of changing research regimes (GIBBONS et al., 1994) and increasing public debates over science (NowOtNy et al., 2001). The strategic nature of science (RIP 2002) and emphasis on innovation further disaggregates this policy area in terms of the involvement of public and private actors at multiple scales. The post-WWII 'Big Science' paradigm, based on the industrialization of science, with laboratories organized like firms around large equipments and international networks, has been replaced by a less centralised and more networked form of research. Such networks have specific territorial dimensions (LAREDO 2003. COOKE AND PICCALUGA 2006). However, the spatial benefits of scientific activities are not evenly spread. 
As in Canada where 'governance by networks' is emerging as a popular form of policy intervention (see SALAZAR AND HOLBROOK, THIS ISSUE), current EU science policy is explicitly designed to network centres of excellence between regions in different European countries. Attention has already been drawn to the potential conflict between European policies aimed at competition and cohesion and the current emphasis on concentration of scientific resources, building economies of scale and networks of excellence will only exacerbate this situation (SHARP, 1998. HERAUD, 2003). This raises key issues relating to the distribution of the scientific and technological expertise on which economic development is predicated and questions over the appropriateness of different scales for action.

The French case is interesting precisely because a decentralised and yet spatially concentrated science policy is anathema to the principles on which the French State is based. The principle of equality, 'égalité', enshrined since the French revolution, has been traditionally interpreted as necessitating a direct and unmediated relationship between the institutions of the French state and each individual citizen, as well as a commitment to balanced growth and regional symmetry. The concept of multi-level governance in science challenges these principles directly through presupposing multiple sources of authority and a decentralised State, as well as the concentration of scientific resources in particular regions. Moreover, for a long time, the French system of research and innovation was said to be "colbertist" (CHESNAIS, 1993). The colbertist system was based on the involvement of the State in science and technology, within a triangle of State, academic research, and industry. However, this model is no longer relevant, as MUSTAR and LAREDO (2002) have shown, since the French system has considerably evolved in the last twenty years. This has largely been through spontaneous or opportunistic moves than through deliberate strategy. Yet the end of 'colbertism' is not the end of State intervention (LANCIANO-MORANDAT and VERDIER 2004). New forms of state intervention have emerged in the context of the drive for excellence, 
competitiveness and cohesion in the European Research Area (ERA), which has highlighted the structural gap between science, technology and innovation in France.

\section{THE EVIDENCE: APPLYING THE THREE TESTS}

\section{A Regional Dimension to French Research and Higher Education Policy}

Throughout the 2000s, France's productivity gap in research and innovation has been widely acknowledged. Relatively high levels of investment in public sector $\mathrm{R} \& \mathrm{D}$, relative to the UK for instance, have not translated into volumes of research outputs, leading to an efficiency dilemma. Public sector research has not been matched by business expenditure on R\&D (BERD) and exploitation has been poor (MINISTERE DELEGUE A LA RECHERCHE ET AUX NOUVELLES TECHNOLOGIES 2003). The blame for such inefficiencies has been consistently placed on a vast and ossified public science and research system, with recurrent and noncompetitive research funding, jobs for life, the absence of a culture of exploitation and a lack of synergy between public research and industry.

The last two years have seen key reforms established to address these issues, with the aim of developing an internationally competitive, economically responsive, efficient, wellstaffed, highly mobile and flexible higher education and research system. Mirroring shifts elsewhere, such as Finland (SOTARAUTA AND KAUTONEN, THIS ISSUE, P.14), recent measures, as summarised in Table 1, have introduced new principles into the French system, notably, the capacity for greater strategic planning and steering in science policy; a shift towards a culture of projects, evaluated on transparent criteria rather than guaranteed recurrent funding for research; and an increased focus on industry-research interactions as a basis for competitiveness and wealth creation. The recent merger of the national Directorates for Research and Technology to create a new Directorate for Research and Innovation can be seen as indicative of this latter aim. 
A feature of these reforms has been an increasing regional dimension to French science and research. New forms of public intervention, budgetary constraints, particularly in relation to university infrastructure, and the importance of the European project have coincided to strengthen the regional dimension to science and research. A regional dimension is also driven by the need to increase the efficiency of the research system and to maximise economic returns from investments in $R \& D$ through spatial clustering and geographic proximity.

New forms of public intervention have become dominant, with policy looking less substantial and more procedural. While the state increasingly defines the rules of the game, it does not specify implementation mechanisms leaving a vacuum between strategic direction and necessary and available policy instruments. Increasingly, science policy is formulated between top-down and bottom-up procedures. Decentralised actors, in particular regional authorities, must respond to proposals and initiatives within a centrally designed framework, corresponding to the type of public action that LANCIANO-MORANDAT and VERDIER (2004) described as the model of "Etat facilitateur". This is a trend that can also be seen in other European countries, such as Germany (KOSCHATZKY AND KROLL, THIS ISSUE). In the French context, key examples include the pôles de competitivité and the réseaux thématiques de recherche avancée (RTRA). The pôles de recherche et d'enseignement supérieur (PRES) represent a slightly different initiative in so far as these are bottom-up developments, not subject to national competition and with no initial dedicated funding attached. The PRES are largely academic collaborations and poorly connected to local actors. Yet despite significant differences in the scale, scope, funding and governance of these initiatives (see Table 1), they all represent varying attempts to bring combinations of academic, industry and local economic actors together within geographically proximate spaces. The emphasis on clusters and networks as tools for economic and scientific development builds on existing regional science 
and innovation infrastructures. However, contrary to the English case, it is important to note that the role of regional authorities has not been restricted to innovation activities; regions are also now welcomed, should they so desire it, as partners in basic science and research as much as exploitation.

\section{INSERT TABLE 1 HERE}

This is particularly relevant in the context of pressures on public spending in science and the recognition by national actors that regional co-financing of science and technology is necessary, if not desirable, for French competitiveness. Budgetary concerns have therefore also diluted the capacity for central control over science, research and higher education. Regional authorities were asked to work with the $6+9$ world-class pôles de compétitivité to help them develop bids for funding to the Agence Nationale de Recherche (ANR) and the Agence de l'Innovation Industrielle (AII) and to give financial priority to those 38 clusters which officially failed to get cluster status in their own spending plans. A recent assessment of progress in the competitiveness clusters estimated regional co-funding at a level of $€ 100 \mathrm{~m}$ (COMmunication En Conseil des Ministres, 30 August 2006). As noted, above, the PRES have no designated funding, yet the most successful will be able to apply for 4-year contracts with the state, following a positive evaluation. Regional financial support may therefore be an important precondition to generating the critical mass and local support necessary to pumpprime potential national resource.

Financing higher education has been a key area in which regional authorities have developed substantial roles, despite having no official competence in this area. Through the programme called Université 2000 (U2000), the state put in place a negotiation procedure in order to involve regions in addressing the huge and rapid investment necessary in university infrastructures (POUYET 1998). In exchange for regional money, the state was forced to concede a role to sub-national authorities as partners in the policy-making process. Cities and 
other sub-national authorities, as well as regional councils, have taken a lead in science and technology policy, driven by the desire to host university or higher education training on their territory. Université du Troisième Millénaire (U3M) was the second large planning operation involving national and sub-national authorities in higher education. The novelty here was the embedding of plans for medium-term academic infrastructures, through the Contrats de Plan Etat-Region (CPER), within a longer-term foresight exercise with various regional actors. University infrastructures have been a large part of the CPER, accounting for $11.5 \%$ of the total allocations in the 2000-2006 planning phase (CIACT 2006). U2000 and U3M were mainly top-down procedures and can be viewed as opportunistic instruments for financing national policy in higher education. But, out of economic necessity, a small revolution emerged leading to the lasting involvement of sub-national authorities in education and science policy.

A third driver of an increasing regional dimension to higher education, science and research is the development of the ERA. Within official documentation, France's active support for the Lisbon challenge of raising R\&D expenditure to 3\% of GDP by 2010 is evident and the Consultation on Research (2003) highlighted widespread support for inter alia: integrating national research policy into a European perspective; bringing French influence to bear on the ERA project; the creation of a European Research Council and a better articulation between European research and university policy. In reality, while an emphasis on centres of excellence can be seen, efforts to increase public and private R\&D to meet the $3 \%$ target have not taken centre stage.

The ERA project has specifically driven increased concern with efficiency, competitiveness and international excellence in science. Yet regionalisation has also been an important corollary to European developments and even a stepping stone to international visibility and world-class excellence. For instance, the RTRA programme aims to encourage 
the emergence of internationally excellent clusters of research, on the basis of the best French research units, but sees geographic proximity as key to this aim. Similarly, the PRES aim for international visibility through creating critical mass at the sub-national level. The resources of regions to participate actively in these initiatives have been enhanced through the recent decentralisation of European regional funds, as part of the reform of the CPER (see below). French reforms are thus marked by a dualism between regional action and international profile.

Recent shifts in French science, research and higher education clearly conceive a key role for regional authorities, not only as financial contributors but as 'active' partners and actors in their own right (see PERRY AND MAY, THIS ISSUE). However, the situation should not be overestimated and a distinction needs to be made between limited devolution in relation to framework policies and the organisations responsible for implementation. Indeed, public research organisations and universities remain fundamentally state-controlled and managed institutions with no necessary orientation towards regional or local needs. Universities are increasing in importance in the French system and are now subject to a process of four-yearly contract planning with the state (MUSSELIN 2001). Yet they remain relatively autonomous public entities with the capacity to engage with regional actors, if not always the disposition. It has been the subject of some debate as to whether regional authorities could be legitimate partners or even signatories in university's contract planning. This has been resisted on the part of some universities contradicting evidence of a 'regionalisation' of university activities (GROSSETTI and LOSEGO 2003).

For their part, national research institutes, such as the Centre National de la Recherche Scientifique (CNRS), have also started to reform their missions and organization with the aim of joining up education, research and innovation and to improve the relationship with universities in the context of increasing 'hybridisation' (MUSTAR and LAREDO 2002). Debates 
have recently developed regarding a potential territorial dimension to this reform and the possible reshaping of CNRS on an inter-regional level. Nevertheless, the decentralisation of CNRS has had greater administrative significance than scientific. On the whole, the orientation of research institutes has remained resolutely international and national. It remains to be seen what the implications of new cluster and pole initiatives might be in altering the geographical orientation of research actors.

The principle of regional equity, if not equality, has also shaped a distinctive French response to the needs of a competitive international knowledge-based economy. Networks and clusters of scientific excellence, rather than the concentration of resources per se, have become preferred policy tools, demonstrating equality of opportunity to compete for science resources, if not equality of outcome. This reflects a more gradual evolution in French policy towards equity rather than equality as a precondition for competitiveness: 'equity represents a means of striving for equality within the reasonable limits of efficiency' (BAUDELLES and PEYRONY 2005, 109). Baudelles and Peyrony note a changing regional development paradigm in which competition between territories is no longer seen as a zero-sum game, a position supported by the rejection of the notion of 'compensatory solidarity' by the most modern and progressive localities (ibid 109).

A good example of the distinctive French response to equality and competition - or equity - is in the pôles de competitivité. It was originally intended that there would be only 15 clusters selected, chosen on the basis of international excellence and visibility, partnership and the capacity for innovation. This form of operation was clearly seen as a way to apply the European approach of networking centres of excellence and is considered as a pathway towards the implementation of the Lisbon strategy. In planning documents, the initiative was conceived of an important tool of industrial policy, driven by a philosophy of 'variable geometry' (CIADT 2004). However, a three-tier system of clusters has subsequently emerged 
representing an attempted balance between competition and balanced growth. Of 105 applications, demonstrating the high degree of local interest in the concept, 67 clusters were eventually funded (now 66 after some regrouping), with priority and preferential conditions given to 6 world-class clusters and 9 second-tier clusters that might join the priority group subject to reaching critical mass. The remaining successful clusters have been designated as being of 'national status' and even those clusters that didn't make it into the 'top 67' have $€ 12 \mathrm{~m}$ earmarked for their development. The geographical distribution of the clusters across France is balanced, with each region participating in at least one cluster, thus highlighting the real limits to French concentration (DATAR 2005). Compared with the UK context, for instance, the location of national research institutes is also deemed a legitimate tool for regional policy, such as in relation to the recent move of the Institut national de recherche sur les transports et leur sécurité (INRETS) to Lyon-Bron (CIACT 2005) or the successful application to host the International Thermonuclear Experimental Reactor (ITER) in Caderache in Provence-Alpes-Côtes-d'Azur (PACA).

\section{Arenas for Negotiation and Contestation}

As with other European countries, the last two decades have seen an evolution of the French administrative system towards greater devolution. What distinguishes the French experience is the way in which devolution to sub-national public authorities - in terms of the transfer of specific competencies - has been accompanied by the decentralisation of the agencies of the central state.

Since the initial decentralisation laws of 1982, the varied sub-national levels - régions, départements and communes - have emerged as increasingly significant actors mediating the relationship between the state and its citizens. In 2003, legal changes strengthened processes of devolution and enshrined the concept of a 'decentralised organisation for the French Republic' within the constitution. Importantly, regions were made constitutionally equal with 
other collectivities and given financial autonomy. In 2005, a second law further defined the transfer of competences from the state to the collectivities, clarified responsibilities between tiers and rationalised local and regional administration. Nevertheless, functional overlap remains. Regional Councils have been given explicit responsibility for economic development, yet other local authorities also have the right to intervene. Départements and local authorities, and more recently intercommunalités (sets of communes regrouped for the sake of specific projects) are now almost as active as regions in the economic field. This is an important point to note, as it is via these economic development functions that sub-national actors have increasingly encroached, from the bottom-up, on the traditionally centralised policy domain of science, research and higher education.

Indeed, sub-national authorities have no constitutional rights to intervene in research and higher education. Science policy is decentralised, through the functions of the Regional Delegation for Research and Technology (DRRT), but not devolved. The DRRT is the representative of national Government in the regions, akin to the English Government Offices for the Regions, taking orders from the Ministry for Research. Yet it is generally considered that the relative autonomy of the regional offices of national ministries and agencies (services déconcentrés de l'Etat) is as important as the existence of devolved authorities for achieving efficient regional governance. The expertise of such "decentralised" teams from the central administration, as well as the room for manoeuvre vis-à-vis the Paris administration, are judged as important success factors in the design of relevant regional policy.

The Republic, however, is decentralised but not federal. Regional autonomy is limited, with variations between some 'historical' regions such as Bretagne (PASQUIER 2003) and Alsace, and those regions without a strong cultural identity. Yet recently, limited flexibility has been introduced through the notion of le droit à l'expérimentation. This established the legality of implementing a devolved function in one (or more) region(s), as a means to 'test' 
an idea. It is consistent with CoLE's (2006: 32) interpretation of decentralisation as a mechanism to 'liberate the entrepreneurial energies and political capacity of local and regional players'. However, the success of any experimental devolution is supposed to lead to the general implementation of the initiative, regardless of the appetite of other regional authorities. This acts as a strong constraint on devolution, since the unanimous willingness of the French regions for greater autonomy cannot be assumed. In this respect, the 'right to experimentation' is a good example of the balance between diversity and equality that characterises the new French political philosophy. Nevertheless, it is an important innovation in French policy. Firstly, national administration will be 'locked in' to changes through the political difficulties of withdrawing any function from a region once it officially granted and successfully trialled. Secondly, local decisions are increasingly being taken in the absence of specific legal competence, science policy being a case in point, and such spontaneous experiments may well be legalised after the fact. The experimentation right is important therefore in creating potential gaps in central state control that can be exploited by subnational authorities to bring about multi-level governance from the bottom-up.

The primary arena for negotiation of national and regional interests in priority setting and policy formulation in all areas of policy is the Contrat de Plan Etat-Régions (CPER). The procedure was introduced in 1982 as a tool for integration between national and regional plans and has subsequently replaced separate plans as the single multi-level negotiation about public objectives, co-funding infrastructures and joint policies between central and regional authorities. There have been four generations of CPER, the last between 2000-2006. Over this period the amounts allocated by the state and regional authorities have tripled (INSTITUT SUPÉRIEUR DES MÉTIERS 2006). In theory the contributions of the central state and regional authorities are equal: in 2000-2006 the $€ 38$ bn total allocations were made up of $€ 19.5 \mathrm{bn}$ from the state compared with $€ 18.5$ bn by regional authorities, in addition to the mobilisation of 
resources by other collectivities (CIACT 2006). Yet, as we discuss below, in practice the balance is less clear, given that the State does not always deliver on its commitments leaving a deficit to be filled by the regions.

The CPER cover all areas of public investments, including science and higher education - to the extent that central and regional authorities have deemed this a priority in different territories. As the regional role in science, research and HE has expanded, as detailed above, so the importance of the CPER as an arena for negotiation in this domain has also increased. Regional authorities, as well as departments and cities in certain cases, have become real partners for science, innovation and higher education policy, negotiating their own priority ranking against the central administration's policy for the territory (BARAIZE 1996). In the negotiation procedure, regional and national interests are compared, leading to various tradeoffs under the general idea of global co-funding. Generally speaking, there are few problems in reaching agreement for investments in areas where the region is obviously leading. However, the increasing competition between regions in strategic areas such as S\&T policy means that the state may be reluctant to co-finance technological or training infrastructures in one region in domains where another region is more advanced. Where disagreements occur, certain projects are $100 \%$ financed either by the state or by the region. Ile-de-France failed to find an agreement with the state on the 'research' part of the CPER and decided to fund a series of projects on its own. Many regions prefer funding education, training and technology transfer than pure research, and are ready to finance a large part of specific projects in those fields. For the current CPER, $83 \%$ of scientific investments (excluding facilities) were realised at the end of 2005. This is due to the high priority attached to higher education and research by the state, contrary to other fields like health and social action, for instance, where only $64.75 \%$ of investments were realised (DIACT, 2006). 
The CPER has been valued in providing an institutionalised space of negotiation between public actors at multiple levels leading to coherence, efficiency and transparency as well as synergy around common objectives. Importantly, a review for the French Senate of the $3^{\text {rd }}$ generation of CPER (ANDRÉ 2000) highlighted how the CPER has been acknowledged as important by regional authorities themselves in the expressions and negotiation of their priorities. Yet the report was also damning of the complexity and bureaucracy of the procedure and the difficulties experienced by regional authorities in an unequal negotiating relationship. It concluded that the state uses an unequal situation to impose its own priorities, without coordinating between ministries or giving the collectivities adequate resources for successful implementation (ANDRÉ 2000: 342).

Such criticisms were not felt to have been rectified in the $4^{\text {th }}$ planning period $(2000$ 2006). The value of CPER to the central state has been judged largely in relation to financial co-funding, in the context of dwindling budgets and fewer tools for intervention. This is particularly relevant in light of the Lisbon objectives and need to increase spending on R\&D. Indeed, the share of the state in contributing to the CPER has steadily dropped over the contract periods, leading to political tensions with most regional councils (INSTITUT SUPÉRIEUR DES MÉTIERS 2006). The relative importance of the CPER as an arena for negotiation remains contested. For instance, public managers within the decentralised administration consider that the national level defines the whole framework for negotiations with little regional variation, while in regional administrations, CPER is viewed as a real arena of negotiation.

In light of these criticisms, a new reform of the CPER has changed the ground rules for the $5^{\text {th }}$ generation of plans 2007-2013 (CIACT 2006). A further driver has also been the European dimension and the need to balance the aims of cohesion and competitiveness. The name has changed to Contrat de Projets Etat-Régions and will focus on 3 main priorities to 
avoid a dispersion of projects and fragmentation of effort: competition and the attractiveness of place; the promotion of sustainable development; and social and territorial cohesion. There will be a focus on national scale investments and a reinforced and flexible partnership with the collectivities. In this respect, regional authorities are now the 'preferred partners' of the state, with an enhanced role for other authorities. Importantly, the CPER is seen as a vital corollary to the "competitiveness clusters" and necessary for reinforcing research effort and the structure of higher education. Although partners are not equal, the CPER provides an important arena for the contestation and negotiation of top-down and bottom-up priorities in science, research and higher education. Central state actors remain dominant but are increasingly passing responsibility for particular elements down to sub-national authorities, in the context of the move to networks and clusters. The mechanisms of the CPER could be used to further institutionalise this involvement.

To this extent, the evidence examined so far would seem to support the argument that science policy is characterised by multi-level governance dynamics in France. New modes of intervention and changes within the specific policy domain of science and research, as well as reform of institutional mechanisms through the right to experimentation and CPER, have led to intersecting, often task-specific and flexible governance arrangements, indicative of type II multi-level governance (HoOGHE and MARKs 2003). A supportive framework for the involvement of sub-national authorities in science, research and higher education exists, with appropriate, if unequal, arenas for the negotiation and contestation of priorities. However, there remain considerable differences in the extent to which regional authorities themselves can capitalise upon this context and seize new opportunities to truly develop science-based economic strategies. It is to this final 'test' that we now turn.

Regional diversity, local implementation 
Whilst the potential exists for regional authorities to adopt greater roles in relation to French science and higher education policy, not all regions are currently in a position to fulfil these functions. Looking first at the data, we see certain differences in regional capacities in relation to science-based economic development. Table 2 outlines indicators of R\&D in French regions. In absolute value, the most important regions are Ile-de-France and RhôneAlpes, together accounting for 55\% of French R\&D. In a second group, we find MidiPyrénées and Provence-Alpes-Côte d'Azur (PACA), followed by Aquitaine and Bretagne. In terms of density (R\&D / GDP), Ile-de-France is surpassed by Midi-Pyrénées, followed by Rhône-Alpes and Auvergne. Differences also emerge in the nature of regional systems. Auvergne appears typical of industry-led research regions, with Franche-Comté, HauteNormandie and Picardie; conversely, Languedoc-Roussillon, Nord-Pas de Calais, Lorraine and Alsace are characterized by the strong contribution of public research. Being a strong R\&D performer does not imply being specialized in high-tech industries or vice versa: here we see that the small region of Limousin appears very high and Auvergne very low.

A further indicator of regional involvement in science and technology is the proportion of regional budgets devoted to S\&T (Table 3). Here again in absolute value the largest regional budgets devoted to Science and Technology (S\&T) are those of Ile-de-France and Rhône-Alpes. In terms of expenses per head, Aquitaine is very high and Rhône-Alpes significant, but smaller regions like Languedoc-Roussillon, Limousin and ChampagneArdenne are among the top five. When looking at the share of S\&T in total regional budgets, Aquitaine is still leading and Languedoc-Roussillon noticeable, followed by Rhône-Alpes and Bretagne. Finally, it is possible to compare the shares of technology transfer and scientific projects (research projects, funding for researchers and scientific information) as indicators of technology-oriented vs. science-oriented policy (SANZ-MENENDEZ \& CRUZ-CASTRO 2005). Here the data indicates that regions like Ile-de-France, Languedoc-Roussillon, Auvergne, 
Alsace and Franche-Comté are mainly interested in technological applications, whereas Bretagne, Rhône-Alpes (and Nord-Pas de Calais, albeit with a weaker global effort on S\&T) manifest a significant relative interest in science. Regional perceptions of science as a strategic target clearly vary strongly.

\section{INSERT TABLE 2 AND TABLE 3}

In terms of results, a clear relation between input and output can be discerned from the data (Table 4), using standard criteria for measuring scientific performance. Among regions with high scientific and technological potential, Ile-de-France and Rhône-Alpes look relatively strong in technological results (patents), whilst Alsace, Languedoc-Roussillon and Midi-Pyrénées also perform well in terms of scientific publications. Ile-de-France, the capital region, leads in terms of the density of $\mathrm{PhD}$ students, clearly ahead of the next regions: Alsace, Midi-Pyrénées and Rhône-Alpes. The number of PhD co-operations between local labs and local firms (see CIFRE index in Table 4) can be used as a potential proxy for indicating systemic coherence of a regional innovation system - here we see again the preeminence of Ile-de-France, but with Midi-Pyrénées and Rhône-Alpes in a strong position.

\section{INSERT TABLE 4}

Overall it appears that science-based activities are largely concentrated in only four key areas. Ile-de-France remains the only region to host a full range of elements which can be seen as constituting an innovation system, though this is synonymous with the national system of innovation. Rhône-Alpes can be considered as the sole regional innovation system in France with key strengths in electronics, nuclear industries, life sciences, medicine and materials. Other regions, like PACA and Midi-Pyrénées, exhibit high-tech districts, but they must be considered more as elements of the national innovation system than real endogenous and self-organized systems. PACA provides an interesting example of a region in transition, however, with Sophia-Antipolis, the first science park in Europe, and the emerging 
developments around Caderache and the ITER facility. Similarly, Midi-Pyrénées provides specific insights to a regional competence in applied science, based heavily around one sector, that of aerospace and clustered in one particular urban area, Toulouse. Across the south of France, a sun-belt of regional innovation systems and science-based regional and local activity is beginning to emerge.

Finance matters and it is clear that the national distribution of resource is significant in this respect. The strong performance of Ile-de-France in terms of $R \& D$ is not due to a high proportion of regional funds invested in S\&T (2.1\% of regional budget, compared with $2.3 \%$ average). Yet the quantitative data only reveal a partial explanation of regional difference, nor does it necessarily relate to those regions that possess genuine regional science policies. The existence of what might be termed 'regional science policy' is determined by the ability of regional authorities to define priorities and express a regional view of science; to master processes of implementation of regional science strategies and to demonstrate leadership in the governance of science and research. In this respect, a general increased interest in S\&T as a driver of sub-national economic growth masks considerable differences in the capacities of different regions to develop science-based development strategies. Within the relatively topdown organisation of the French system, implementation processes provide an opportunity for variety and self-organisation to emerge.

Firstly, the relative magnitude of intergovernmental negotiation mechanisms, such as the CPER, is variable. The average level of regional councils' participation in CPER is $35 \%$ (IGAENR, 2005) yet this rises to $50 \%$ or even $80 \%$ for certain regions, such as PACA. For other regions, such as Ile-de-France and Rhône-Alpes the amounts are lower than 30\%, leaving greater room for the definition of regional priorities independent of national state preferences. Within CPER, regional councils may also encounter difficulties in defining a clear 'regional interest' given the nature of sub-national governance arrangements and the 
strength of other collectivités such as departments and cities. This is particularly the case in strong university towns, such as Strasbourg. Here the tension between regional and local levels becomes particularly apparent: the political acceptability of a regional science policy which leads to concentration of resources in particular locations is low and seen to be contrary to the need for balanced growth. As a result, science and HE policy develops as a local issue, rather than a regional one. Competition can therefore arise between local and regional levels where sub-regional levels want to define their own priorities, rather than participate in a wider regional strategy, which in turn constrains collective action.

The formal expression of regional science and higher education priorities also differs cross-regionally. Four elements are important in understanding the nature of regional action: the size of the region; the nature of the regional science infrastructure; the type of firms and the structure of the productive fabric; and the specific scientific/technological fields of importance in the region. Socio-political elements have to be taken into account as well, linked to regional identity and cultural attitudes concerning science, academic freedom or the desirability and extent of public-private partnerships. In Alsace, a historical province with a strong collective identity, regional authorities are very proactive in relation to devolution, but this attitude is not specifically blatant in the field of science. At the same time, whilst science is not necessarily a priority for a region, even if they have strong scientific or technological endowments, other policies such as education and training, employment and inclusion may have secondary implications for scientific and research establishments.

These differences are reflected in the use made of formal regional consultative committees on research (CCRRDT) - involving representatives of a large variety of regional actors, in particular from research and industry - with some regions, such as Rhône-Alpes or Midi-Pyrénées, more proactive than others, where a regular regional meeting is organized to debate on science issues at regional level. Since 1982, regional councils are supposed to 
benefit from their expertise, yet not all regions have created CCRRDT at the same time, under the same form, and for the same purpose. Midi-Pyrénées or Bretagne developed and maintained a strong CCRRDT, whilst Alsace has a symbolic committee with only a very limited role. Ile-de-France created its own scientific forum (called CCRRESTI) as late as 2003. Before 2005, in PACA, the main task of the CCRRDT was regional foresight, whereas in Bourgogne or Midi-Pyrénées, it takes part in expertise process-making.

What emerges from this analysis is a picture of regional differentiation - in terms of the position from which different regions can engage with and capitalise upon the changing national science policy context, as well as develop policies from the bottom up. Yet the data can be misleading - it is not simply the case that a strong science base provides for a coherent regional science policy. Indeed, four rationales for regional science policy in France emerge (see Figure 1):

- Regions that have regional science policies because they have a strong science base (Rhône-Alpes is the paradigm);

- Regions with regional science policies because they want to develop their science base (like Bretagne);

- Regions with weak regional science policies and an average or weak science base (like Auvergne);

- Regions with a strong science base yet weak regional science policies (like Alsace).

\section{INSERT FIGURE 1}

This last rationale illustrates the situation in most regions. In Alsace, basic research is proportionally strong, with many world-known university and CNRS teams, but the regional 
council does not have a real strategy of promoting such academic assets as a tertiary activity per se: its perception of basic research is more about the possible impact it could have on the local industrial fabric, although there is a mismatch here as regional firms are generally not science-based. In contrast, in Lorraine around Nancy, education and research activities are fully welcomed as a substitute for declining industrial activities. Paradoxically, for a long time, research has not been a priority for the region of Ile-de-France, probably because the S\&T system around Paris was viewed as a mainly national construction. But local/regional politicians have become aware of the necessity for Ile-de-France to remain a strong region in international competition for high-level tertiary activities and now have a pro-active attitude. The importance of national investment within Ile-de-France has already been noted, explaining in part the relatively modest ambitions of the regional council. With the introduction of new mechanisms, such as pôles de compétitivité, general changes in attitude can be seen across all regions. Yet even in this case, increased regional involvement in national science policy does not automatically imply the existence of a real policy at the subnational level.

Regional science strategy is not linked to the presence of scientific activities in a simple and linear way. We have indicated here that several factors explain differences between regions and their interpretations of and responses to changes in national science policy. Further case study research is needed to determine the relative balance of these factors and how they interact to produce distinct regional contexts and capacities for action. The modest conclusions that we can draw at this stage are three-fold. Firstly the available evidence indicates substantial differences in the positions from where regions engage with the emerging multi-level system of science policy governance in France. Secondly, whilst national policy conceives of a role for the regions, there remains little evidence that the phenomenon of regional science policies is well-spread across regions. Thirdly, only four 
regions could be said to be developing into 'science regions' which raises questions over the long-term viability of the French policy of equity, if not equality.

\section{A SYSTEM IN EVOLUTION?}

To what extent can multi-level governance be said to characterise science policy in France? The evidence is partial, indicating that the potential for multi-level governance has not been realised in practice. Shifts in science policy governance reflect ongoing processes rather than being fixed in time.

During the last decade, the traditional philosophy of centralised policy design and implementation has changed more in reality than officially advertised. The financial context has encouraged the French state to share certain functions relating to science, research and higher education with local and regional authorities, leading to a more complex governance organisation. More recently another shift in policy can be observed, with (at least partial) bottom-up and competitive procedures being encouraged at the national level. New instruments like "competitiveness clusters" or PRES are designed at the initiative of decentralised actors (universities, territorial communities, firms) and only subsequently 'labelled' by the central administration. The example of science policy thus also offers insights into the restructuring of the French administration, in terms of forms of public interventionism, new modes of steering and management and the involvement of the regions in the necessary reconstruction of a globally competitive state. Government is creating frameworks that have to be shaped by territorial configurations, leading to more selective action and resource concentration.

Within new national frameworks, regions are emerging as intermediate actors within complex governance structures. It is not likely that regional councils can be "the dominant player" but they can mobilise both sub-regional and supra-regional levels to implement their own strategies. Spaces for the negotiation of science policy between national and regional 
actors have been created and regional science policies are beginning to emerge in certain regions. Some of these spaces are institutionalised like the CPER negotiation; others are created ad hoc in relation to particular initiatives. However, the French system is less characterized by uniformity of regional organisations than it might at first seem. Only two strong (Ile-de-France and Rhône-Alpes) and two emerging contenders (PACA and MidiPyrénées) emerge in terms of participation within a multi-level science polity. As the case of Strasbourg illustrates, it might even be that alternative scales emerge as more relevant for the construction of local science priorities, such as cities, city-regions or departments. Despite identical institutional structures, patterns of implementation diverge.

The emerging dynamics of a multi-level science system therefore pose challenges to a traditional centralised French state, with its commitment to balanced growth and regional symmetry. New compromises between concentration and balanced growth have been struck through networking inter-regional groupings and offering equality of opportunity through national competitions. Yet, the principle of territorial equality can no longer be seen as a strict rule in national policy: the success of top-down initiatives (and the corresponding distribution of resources) depends inherently on the willingness and the capacities of the territories. Within an increasingly regionally-sensitive national framework, it is the capability of actors at the regional level that determines the extent of multi-level governance in different arenas.

From a theoretical perspective, it is this issue that appears most interesting. This analysis has highlighted three prerequisites for the development of a multi-level polity: a national framework that envisages, or even depends on, regional action for the successful implementation of its policies; arenas for negotiation of national and regional 'priorities' and the capacities and capabilities of regional actors to develop clear strategies from the bottomup. In this case, we see that the central Government remains the key actor in science policy. The state holds the greatest bargaining power and the mobilisation of sub-national authorities 
3

4

5

6

7

8

9

10

11

12

13

14

15

16

17

18

19

20

21

22

23

24

25

26

27

28

29

30

31

32

33

34

35

36

37

38

39

40

41

42

43

44

45

46

47

48

49

50

51

52

53

54

55

56

57

58

59

60

in this domain can be seen, at one level, as little more that a way to increase steering capacity and reduce budgetary pressures. Nevertheless, as a result, relations between the national and the sub-national level are becoming less hierarchical. Interdependence is prevalent. Despite a top-down framework that is beginning to see the regional scale of action as relevant for achieving national objectives and international aspirations, regional awareness of science and research as drivers of economic growth remains low. The tools for multi-level governance to develop exist in this field as in many others; but, as yet, the political context for its materialisation is not present in every region. 
TABLE 1

Table 1

Selected Recent Developments in French Science, Research and Innovation, 2004-2006 
TABLE 2

\section{Table 2: Indicators of R\&D in French regions $(2003)^{i}$}

\begin{tabular}{|c|c|c|c|c|c|}
\hline $\begin{array}{l}\text { French Regions } \\
\text { overseas areas) }\end{array}$ & $\begin{array}{c}\text { Total R\&D } \\
\text { expenses } \\
\text { (M€) }\end{array}$ & $\begin{array}{l}\text { R\&D expenses } \\
\text { in \% of GDP }\end{array}$ & \begin{tabular}{|c|}
$\begin{array}{c}\text { Share of firms } \\
\text { in R\&D expenses } \\
(\%)\end{array}$ \\
\end{tabular} & $\begin{array}{c}\text { Share of high tech } \\
\text { sectors in firms' } \\
\text { R\&D expenses } \\
(\%) \\
\end{array}$ & $\begin{array}{c}\text { Share of } \\
\text { researchers } \\
\text { in total R\&D } \\
\text { employees }(\%)\end{array}$ \\
\hline Alsace & 692 & 1.6 & 55 & 42 & 49 \\
\hline Aquitaine & 1147 & 1.6 & 70 & 12 & 47 \\
\hline Auvergne & 689 & 2.4 & 80 & 2 & 34 \\
\hline Basse-Normandie & 298 & 1.0 & 65 & 21 & 52 \\
\hline Bourgogne & 359 & 1.0 & 70 & 43 & 44 \\
\hline Bretagne & 1097 & 1.6 & 62 & 14 & 54 \\
\hline Centre & 869 & 1.5 & 76 & 36 & 41 \\
\hline Champagne-Ardenne & 8 & 0.8 & 74 & 44 & 48 \\
\hline Corse & $r^{2}$ & na & na & na & na \\
\hline Franche-Comté & 530 & 2.1 & 86 & 88 & 45 \\
\hline Haute-Normandie & 601 & 1.4 & 84 & 37 & 40 \\
\hline Ile-de-France & 14364 & 3.2 & 68 & 33 & 53 \\
\hline Languedoc-Roussillon & 988 & 2.0 & 29 & 13 & 48 \\
\hline Limousin & 124 & 0.8 & 60 & 87 & 45 \\
\hline Lorraine & 547 & 1.1 & 46 & 40 & 47 \\
\hline Midi-Pyrénées & 2283 & 3.7 & 65 & 12 & 59 \\
\hline Nord-Pas-de-Calais & 580 & 0.7 & 45 & 30 & 51 \\
\hline Pays de la Loire & 756 & 1.0 & 60 & 25 & 49 \\
\hline Picardie & 438 & 1.1 & 83 & 36 & 48 \\
\hline Poitou-Charentes & 305 & 0.8 & 56 & 46 & 46 \\
\hline $\begin{array}{l}\text { Provence-Alpes-C. d'Azur } \\
+ \text { +Corse }\end{array}$ & 2113 & 1.8 & 20 & 15 & 56 \\
\hline Rhône-Alpes & 3896 & 2.6 & 68 & 33 & 50 \\
\hline France (22 regions) & 32913 & 2.1 & 66 & 30 & 51 \\
\hline
\end{tabular}


TABLE 3

Table 3: Indicators of French regional policies: Analysis of regional councils' RTD budgets ${ }^{\text {ii }}$

\begin{tabular}{|c|c|c|c|c|c|}
\hline \multirow{2}{*}{$\begin{array}{l}\text { French Regions } \\
\text { overseas areas) }\end{array}$ (non } & \multirow{2}{*}{$\begin{array}{l}\text { Sc\&Tech } \\
\text { regional budget } \\
\text { (M€) }(*)\end{array}$} & \multirow{2}{*}{$\begin{array}{c}\text { Sc\&Tech } \\
\text { regional budget } \\
\text { per head (*) }\end{array}$} & \multirow{2}{*}{$\begin{array}{c}\text { Share of } \mathbf{S c} \& T \\
\text { in regional } \\
\text { budget }(*)\end{array}$} & \multicolumn{2}{|c|}{$\begin{array}{l}\text { Share (\%) of Sc\&T regional budget } \\
\text { devoted to: }(* *)\end{array}$} \\
\hline & & & & $\begin{array}{c}\text { Technology } \\
\text { transfer }\end{array}$ & Scientific projects \\
\hline Alsace & 10.0 & 5.6 & 2.1 & 31 & 36 \\
\hline Aquitaine & 36.1 & 12.0 & 5.5 & 11 & 27 \\
\hline Auvergne & 2.8 & 2.1 & 0.7 & 30 & 21 \\
\hline Basse-Normandie & 10.1 & 7.0 & 2.5 & 6 & 36 \\
\hline Bourgogne & 8.1 & 5.0 & 2.2 & 11 & 27 \\
\hline Bretagne & 19.9 & 6.7 & 3.1 & 19 & 54 \\
\hline Centre & 2 & 4.0 & 1.6 & 10 & 36 \\
\hline Champagne-Ardenne & 10.4 & 7.8 & 3.0 & 9 & 48 \\
\hline Corse & 1.8 & 6.5 & 0.4 & 17 & 53 \\
\hline Franche-Comté & 7.9 & 7.0 & 2.8 & 35 & 46 \\
\hline Haute-Normandie & 7.8 & 4.4 & 1.5 & 18 & 37 \\
\hline Ile-de-France & 59.9 & 5.4 & 2.1 & 17 & 4 \\
\hline Languedoc-Roussillon & 20.3 & 8.4 & 3.9 & 19 & 10 \\
\hline Limousin & 5.4 & 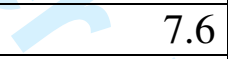 & 2.5 & 6 & 23 \\
\hline Lorraine & 8.1 & 2.6 & 1.2 & 18 & 42 \\
\hline Midi-Pyrénées & 16.8 & 6.3 & 2.4 & 21 & 30 \\
\hline Nord-Pas-de-Calais & 11.8 & 2.9 & 1.0 & 18 & 62 \\
\hline Pays de la Loire & 28.4 & 6.4 & 2.9 & 9 & 35 \\
\hline Picardie & 12.4 & 6.6 & 2.4 & 15 & 43 \\
\hline Poitou-Charentes & 7.2 & 4.3 & 1.9 & 12 & 41 \\
\hline Provence-Alpes-C. d'Azur & 19.7 & 4.3 & 1.9 & 10 & 24 \\
\hline Rhône-Alpes & 42.4 & 7.3 & 3.1 & 23 & 48 \\
\hline France (22 regions) & 347.9 & 5.8 & 2.3 & 16 & 30 \\
\hline
\end{tabular}




\section{TABLE 4}

\begin{tabular}{|c|c|c|c|c|}
\hline $\begin{array}{c}\text { French Regions } \\
\text { overseas areas) }\end{array}$ & $\begin{array}{l}\text { Index of scientific } \\
\text { publications } \\
\text { per head } \\
(2001)\end{array}$ & $\begin{array}{c}\text { Index of patents : } \\
\text { European P.O. } \\
\text { applications } \\
\text { per head } \\
(2001) \\
\end{array}$ & $\begin{array}{l}\text { PhD students for } \\
100000 \text { inhabitants } \\
\text { (2001) }\end{array}$ & $\begin{array}{l}\text { Index of CIFRE } \\
\text { PhD in the same } \\
\text { region } \\
(*)\end{array}$ \\
\hline Alsace & 142 & 121 & 22.7 & 110 \\
\hline Aquitaine & 80 & 37 & 16.7 & 121 \\
\hline Auvergne & 74 & 72 & 10.7 & 81 \\
\hline Basse-Normandie & 52 & 45 & 7.7 & 121 \\
\hline Bourgogne & 50 & 73 & 7.7 & 48 \\
\hline Bretagne & 70 & 58 & 10.7 & 132 \\
\hline Centre & 48 & 79 & 6.7 & 85 \\
\hline Champagne-Ardenne & 36 & 52 & 5.2 & 51 \\
\hline Corse & na & na & na & na \\
\hline Franche-Comté & 54 & 90 & 10.2 & 85 \\
\hline Haute-Normandie & 43 & 79 & 6.7 & 59 \\
\hline Ile-de-France & 206 & 227 & 31.9 & 169 \\
\hline Languedoc-Roussillon & 122 & 43 & 17.3 & 77 \\
\hline Limousin & 58 & 35 & 13.1 & 81 \\
\hline Lorraine & 80 & 59 & 15.3 & 103 \\
\hline Midi-Pyrénées & 119 & 75 & 19.4 & 151 \\
\hline Nord-Pas-de-Calais & 55 & 33 & 8.7 & 125 \\
\hline Pays de la Loire & 53 & 47 & 7.2 & 99 \\
\hline Picardie & 30 & 67 & 5.7 & 63 \\
\hline Poitou-Charentes & 47 & 44 & 11.1 & 70 \\
\hline $\begin{array}{l}\text { Provence-Alpes-C. d'Azur } \\
+ \text { Corse }\end{array}$ & 95 & 74 & 15.9 & 132 \\
\hline Rhône-Alpes & 130 & 173 & 18.2 & 136 \\
\hline France ( 22 regions) & 100 & 100 & 15.8 & 100 \\
\hline
\end{tabular}

Sources:

OST, Indicateurs de Science et de Technologies, Economica, Paris, 2004. Also Héraud and Lévy (2005). (*) Statistics measuring the frequency of CIFRE PhD projects between a firm and a scientific lab, both of them being located in the same region. It is an indicator of the capability of a region to behave as a consistent system of innovation. 


\section{FIGURE 1}

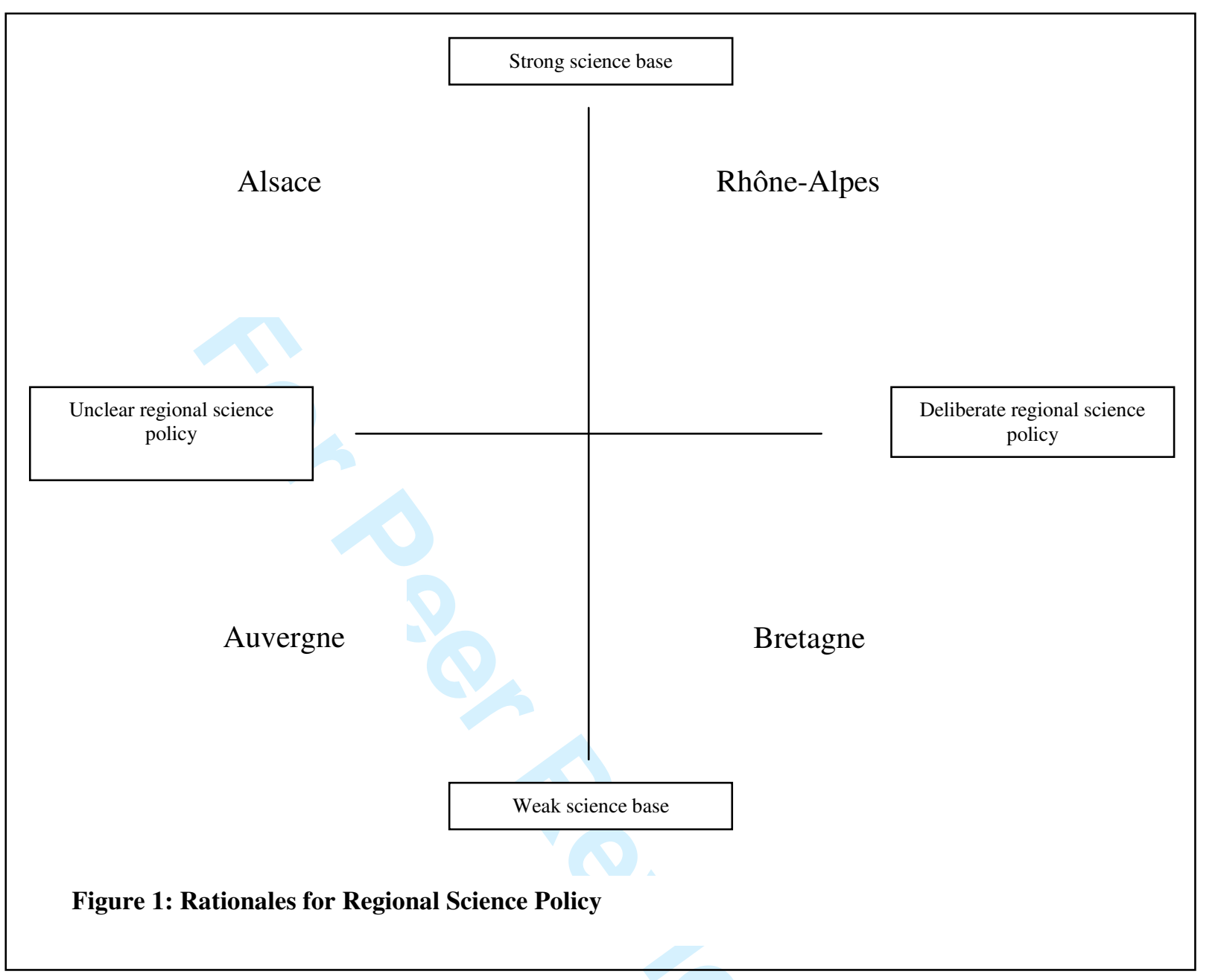




\section{REFERENCES}

ANDRE P. (2000) Rapport d'information fait au nom de la délégation du Sénat pour la planification sur les troisièmes contrats de plan Etat-Régions (1994-1999). No. 466. Sénat session ordinaire de 1999-2000. La Documentation Française, Paris.

BACHE I. and FLINDERS M. (Eds) (2004) Multi-Level Governance. Oxford University Press, Oxford.

BACHE I. and FLINDERS M. (Eds) (2004) Multi-level governance and British Politics, in BACHE I. and FLINDERS (Eds) Multi-Level Governance, pp. 93-106. Oxford University Press, Oxford.

BARAIZE F. (1996) L'entrée de l'enseignement supérieur dans les contrats de plan EtatRégions : la mise en réseau de la décision universitaire in GAUDIN J.P. (Eds), La négociation des politiques contractuelles. pp.133-67. L'Harmattan, Paris.

BARRE R., GIBBONS M., MADDOX J. and MARTIN B. (1997) Science in Tomorrow's Europe. Economica, Paris.

BAUDELLES G. and PEYRONY J. (2005) Striving for equity: polycentric development policies in France, Built Environment 31(2), 103-11.

BENZ A. and EBERLEIN B. (1999) The Europeanisation of regional policies: patterns of multi-level governance, Journal of European Public Policy 6(2), 329-48. 
CHABBAL R. (1995) Characteristics of innovation policies, namely for SMEs', STI Review 16, 103-40.

CHESNAIS F. (1993) The French national system of innovation, in NELSON R. (Ed) National innovation systems, pp.192-229. Oxford University Press, Oxford.

COLE A. (2006) Decentralisation in France: central steering, capacity building and identity construction, French Politics 4, 31-57.

COMITE INTERMINISTERIEL D'AMENAGEMENT ET DE DEVELOPPEMENT DU TERRITOIRE (CIADT) (2004) Dossier de Presse. La Documentation Française, Paris.

COMITE INTERMINISTERIEL D'AMENAGEMENT ET DE COMPETIVITE DES TERRITOIRES (CIACT) (2005) Dossier de presse. La Documentation Francaise, Paris.

COMITE INTERMINISTERIEL D'AMENAGEMENT ET DE COMPETIVITE DES TERRITOIRES CIACT (2006) Dossier de presse. La Documentation Francaise, Paris.

COMMUNICATION EN CONSEIL DES MINISTRES (2006) Le bilan des pôles de compétitivité. Press release. Ministry of Industry and Ministry of regional development.

CONZELMANN T. (1995) Networking and the Politics of EU Regional Policy: Lessons from North Rhine-Westphalia, Nord-Pas de Calais and North West England, Regional and Federal Studies 5(2), 134-72. 
CONZELMANN T. (1998) 'Europeanisation’ of Regional Development Policies? Linking the Multi-level Governance Approach with Theories of Policy Learning and Policy Change, European Integration online Papers, http://eiop.or.at/eiop/texte/1998-004a.htm

COOKE P. and PICCALUGA A. (Eds) (2006) Regional Development in the Knowledge Economy. Routledge, Oxon.

DATAR (2005) Les Pôles de compétitivité. Observatoire des territoires. La Documentation Francaise, Paris.

DEAN M. (1999) Governmentality: Power and Rule in Modern Society. Sage Publications, London.

DIACT (2006) Avancement des CPER 2000-2006 par Ministère. http://www.diact.gouv.fr

EDLER J., KUHLMANN S. and BEHRENS M. (2003) Changing Governance of Research and Technology Policy: The European Research Area. Edward Elgar, Cheltenham.

EUROPEAN COMMISSION (2001) The Regional Dimension of the European Research Area. COM 549 final. Commission of the European Communities, Luxembourg.

FAIRBRASS J. and JORDAN A. (2004) Multi-level governance and environmental Policy, in BACHE I. and FLINDERS M. (Eds) Multi-Level Governance, pp. 147-64. Oxford University Press, Oxford. 
GIBBONS M., LIMOGES C., NOWOTNY H., SCHWARTZMANN S., SCOTT P. and TROW M. (1994) The new production of knowledge. The dynamics of science and research in contemporary societies. Sage Publications, London.

GROSSETI M. and LOSEGO P. (2003) La territorialisation de l'enseignement supérieur et de la recherche - France, Espagne et Portugal. L'Harmattan, Paris.

HAIGNERE C. (2002) Communique de presse. Ministère délégué à la recherche et aux nouvelles technologies. La Documentation française, Paris.

HÉRAUD J-A. (2003) Regional innovation systems and European research policy: Convergence or misunderstanding?, European Planning Studies 11(1), 41-56.

HÉRAUD J-A. and LÉVY R. (2005) University-Industry Relationships and Regional Innovation Systems: Analysis of the French Procedure Cifre, in LLERENA P. and MATT M. (Eds), Innovation Policy in a Knowledge-Based Economy. Theory and Practice, pp.193-219. Springer, Heidelberg.

HOOGHE L. and MARKS G. (2003) Unravelling the Central State, But How? Types of Multi-Level Governance, American Political Science Review 97 (2), 233-43.

\footnotetext{
INSPECTION GENERALE DE L'ADMINISTRATION DE L'EDUCATION NATIONALE ET DE LA RECHERCHE (IGAENR) (2005) Recherche et territoires. La Documentation française, Paris.
} 
INSTITUT SUPERIEUR DES METIERS (2006) Contrats de projets Etat-Régions. Observatoire des aides aux petites entreprises et du développement économique, http://observatoire.ism.asso.fr/

JEFFREY C. (1996) Regional Information Offices in Brussels and Multi-level governance in the EU: A UK - German comparison, Regional and Federal Studies 6 (2), 182-203.

JOHN P. (1996) Europeanisation in a Centralising State: Multi-level Governance in the UK, Regional and Federal Studies 6 (2), 131-43.

JORDAN A. (2001) The European Union: An Evolving System of Multi-Level Governance ... or Government?, Policy and Politics 29 (2), 193-208.

KAISER R. (2003) Multi-level Science Policy and regional innovation: The Case of the Munich Cluster for Pharmaceutical Biotechnology, European Planning studies 11 (7), 841-57

KEATING M. (1998) Is there a regional level of government in Europe?, in LE GALÈS P. and LEQUESNE C., Regions in Europe, Routledge, London, pp. 11-30.

KITAGAWA, F. (this issue) The Regionalisation of Science and Innovation Governance in Japan? Regional Studies.

KOOIMAN J. (1990) Modern governance. New government-Society interactions. Sage Publications, London. 
KOSCHATZKY, K. and KROLL, H. (this issue) Which side of the coin? The regional governance of science and innovation. Regional Studies.

LANCIANO-MORANDAT C. and VERDIER E. (2004) Dynamiques des régimes sociétaux d'enseignement supérieur et d'innovation, Revue internationale de politique comparée 11(3), $369-87$.

LAREDO P. (2003) Six major challenges facing public intervention in higher education, science, technology and innovation, Science and Public Policy 30(1), 4-12.

LE GALES P. and LEQUESNE C. (1998) Regions in Europe. Routledge, London.

MARKS G. (1993) Structural Policy and Multi-level Governance in the EC, in CAFRUNY A.W. and ROSENTHAL G. (Eds), The State of the European Community: Vol. 2 The Maastricht Debates and Beyond, pp. 391-410. Lynne Rienner Publishers, Harlow.

MCALEAVY P. and DE RYNCK S. (1997) Regional or Local? The EU's Future Partners in Cohesion Policy, European University Institute, Working Paper RSC no. 97/55, http://www.iue.it/RSC/WP-Texts/97_55.html.

\footnotetext{
MINISTERE DELEGUE A LA RECHERCHE ET AUX NOUVELLES TECHNOLOGIES

(2003) Avenir de la recherche: document introductif aux réflexions et aux discussions sur l'avenir de la recherche française. La Documentation Française, Paris.
} 
MINISTERE DE L'EDUCATION NATIONALE, DE L'ENSEIGNEMENT SUPERIEUR ET DE LA RECHERCHE (2006) Note Recherche. www.education.gouv.fr/stateval

MINISTERE DE L'EDUCATION NATIONALE, DE L'ENSEIGNEMENT SUPERIEUR ET DE LA RECHERCHE (2006) Special enquiry on local governments' budgets.

MUSSELIN C. (2001) La longue marche des universités françaises. Presses universitaires de France, Paris.

MUSTAR P. and LAREDO P. (2002) Innovation and research policy in France (1980-2000) or the disappearance of the Colbertist State, Research Policy 31(1), 55-72.

NOWOTNY H., GIBBONS M. and SCOTT P (2001) Rethinking Science. Knowledge and the Public in an Age of Uncertainty. Polity Press, Cambridge.

OHMAE K. (1993) The rise of the region state. Foreign Affairs 72 (2), 78-87.

OST (2004) Indicateurs de sciences et technologies, Rapport de l'Observatoire des sciences et des techniques. Economica, Paris.

PASQUIER R. (2003) La régionalisation française revisitée : fédéralisme, mouvement régional et élites modernisatrices (1950-1964), Revue française de science politique 53(1), 101-25. 
PERRATON J. and WELLS P. (2004) Multi-level governance and Economic Policy, in BACHE I. and FLINDERS M. (Eds) Multi-Level Governance. Oxford University Press, Oxford, pp. 179-94.

PERRY, B. (this issue) The multi-level governance of science policy in England. Regional Studies.

PERRY, B. and MAY, T. (this issue) Governance, science policy and regions: an introduction. Regional Studies.

PETERS B. GUY and PIERRE J. (2001) Developments in intergovernmental relations: towards multi-level governance, Policy and Politics 29(2), 131-35.

PETERS B. GUY and PIERRE J. (2004), Multi-level governance and Democracy: A Faustian bargain, in BACHE I. and FLINDERS M. (Eds) Multi-Level Governance, pp. 75-89. Oxford University Press, Oxford.

POUYET B. (1998) Une réforme de l'université par les moyens, in Développement universitaire et développement territorial. L'impact du plan U2000. La Documentation française, Paris.

REIGNER H. (2001) Multi-level governance or co-adminstration? Transformation and continuity in French local government, Policy and Politics 29(2), 181-92. 
RIP A. (2002) Regional Innovation Systems and the Advent of Strategic Science, Journal of

Technology Transfer 27, 123-31.

SALAZAR, M. and HOLBROOK, A. (this issue) Canadian STI Policy: the product of regional networking? Regional Studies.

SANZ-MENENDEZ L. and CRUZ-CASTRO L. (2005) Explaining the science and technology policies of regional governments, Regional Studies 39(7), 939-54.

SHARP M. (1998) Competitiveness and cohesion - are the two compatible?, Research Policy 27(6), 569-88.

SOTARAUTA, M. and KAUTONEN, M. (this issue) Co-evolution of the Finnish National and Local Innovation and Science Arenas: Towards a Dynamic Understanding of Multi-Level Governance. Regional Studies.

STOKER G. (1998) Governance as theory: five propositions, UNESCO International Review of the Social Sciences 155, 19-30.

THOENIG J.-C. (2005) Territorial administration and political control: decentralization in France, Public administration 83 (3), 685-708.

\footnotetext{
${ }^{\mathrm{i}}$ The numbers in bold characters are the maximum and the minimum of each column. Ile de France and RhôneAlpes (stressed in grey) clearly emerge, in absolute and relative terms, as leading territories for S\&T research in general. Other regions are important for some specificities only: Midi-Pyrénées in R\&D intensity and in the proportion of researchers; Franche-Comté, Haute-Normandie and Picardie in firms R\&D; Franche-Comté and Limousin for the share of high tech sectors in firms' R\&D.

${ }^{\text {ii }}$ The numbers in bold characters are the maximum and the minimum of each column. Bretagne and RhôneAlpes (stressed in grey) show particularly high figures in terms of budgetary investments in scientific projects, as well as for the global effort in S\&T, relative to their size. Regions like Alsace or Auvergne express choices that are clearly more oriented towards technology transfer than the average of France, and Ile de France funds
} 
proportionally very few scientific projects: it is not possible to rank them among the champions of regional science policy, to the contrary of Bretagne and Rhône-Alpes.

iii The numbers in bold characters are the maximum and the minimum of each column. Ile de France, RhôneAlpes, Alsace and Midi-Pyrénées (stressed in grey) show important scores for most of the indicators. But the last column shows that Alsace has not a very high degree of self-sufficiency in science-industry relationships. 